\title{
Zimbabwean Manufacturing Firms' Propensity and Intensity to Export in the Post Zimbabwean Dollar
} Era

\author{
Nathan Mugumisi \\ Lupane State University, Zimbabwe \\ nmugumisi@lsu.ac.zw
}

\begin{abstract}
After the adoption of the multicurrency system in 2009 Zimbabwe's macroeconomic environment stabilized but the new economic order exposed the economy to a crippling liquidity crisis. Exports remain the only sustainable solution to Zimbabwe's liquidity crisis in the short to medium term given the current sanctions that limits other international capital flows. This study sort to understand the factors that determine Zimbabwean manufacturing firms' likelihood and intensity to export. The study a was based on panel data from a 19 manufacturing firms listed on the Zimbabwe Stock Exchange over the period 2009 to 2017. The propensity and intensity to export was estimated using the logit and Tobit regression models respectively. Bigger firms and firms that engage in research and development had a high propensity to export. Foreign owned firms and firms that engage in research and development had a high intensity to export, while those with high domestic turnover tended to export less. The appreciation of the USD increased Zimbabwean manufacturing firms' propensity and intensity to export. We urge the policy makers to design investment laws that attract foreign investors, and managers to prioritize research and development. We also recommend firm managers to take advantage of periods of currency appreciation to recapitalize at a cheaper cost and export more goods since Zimbabwe's manufacturing production is highly import dependent.
\end{abstract}

Key words: Export intensity, export propensity, manufacturing firm, Zimbabwe, multicurrency system

\section{Introduction}

After embarking on the fast track land reform program in year 2000 to redress the land distribution imbalances, Zimbabwe's relations with the Western countries deteriorated rapidly, culminating to the imposition of sanctions on Zimbabwe and withdrawal of balance of payment support. This triggered an economic meltdown which resulted in an economic contraction of over $40 \%$ between year 2000 and 2008 due to a myriad of challenges which included hyper-inflation, company closures, and political crisis. Zimbabwe's hyper-inflation reached a record level of 231 million per cent by mid-2008. In February 2009, Zimbabwe abandoned its own currency and adopted a multicurrency system after episodes of currency competition and asset substitution. Five foreign currencies namely the US dollar, the British pound, the South African rand, the EU euro and the Botswana pula, were adopted to replace the Zimbabwe dollar. Ever since the adoption of the multicurrency system, the economy turned around and the macroeconomic environment stabilized. The new economic order however exposed the economy to serious liquidity challenges (Mugumisi \& Ndhlovu, 2015). The liquidity crunch limits banks' ability to fund firms' working capital and equipment requirements, and seriously constraints the public ability to transact especially in emerging economies where payment platforms are traditional. Within the auspices of a multiple currency system, the central bank does not issue currency, liquidity sources are limited (RBZ, 2012). Under the MCS money supply is a function of the performance of the export sector, international capital inflows (foreign direct investment and portfolio investments), diaspora remittances, external lines of credit and donor funds (RBZ, 2012). In this respect the Zimbabwe's liquidity situation is a function of developments in the external sector.

Given the sanctions imposed on Zimbabwe since the turn of the century, exports remain the most viable panacea to Zimbabwe's liquidity problems. Zimbabwe has however perennially suffered a balance of payment deficits that preludes the multicurrency system. Zimbabwe's trade deficit worsened from US\$1.1 billion in 2008 to reach a peak of US $\$ 5$ billion in 2011 before slightly improving to US $\$ 3.9$ billion in 2013 and US $\$ 3.3$ billion in 2014 (RBZ, 2015). Manufacturing export performance between 2014 and 2015 indicated a declining or shrinking capacity to export, RBZ statistics show that manufactured exports declined by $7 \%$ from 2014 to 2015 (www.zimtrade.co.zw, March 2016). In a bid to boost export performance, reverse the widening trade deficit, and arrest the crippling liquidity crisis, the government of Zimbabwe implemented a number of initiatives. One of the key initiatives is the Export Incentive Scheme (EIS) introduced in May 2016 to enhance export competitiveness and boost export earnings. Under the EIS, the government, through the 
Reserve Bank of Zimbabwe, would pay up to $5 \%$ bonus to exporters of goods and services. The 5\% was payable in Bond notes backed by the US $\$ 200$ million African Export Import Bank Nostro Stabilization and Export Finance Facility. According to the RBZ midterm monetary policy review 2017 of August 2017, Zimbabwe experienced a $4 \%$ increase in foreign currency receipts and a $14 \%$ increase in exports since the introduction of the EIS. Although the government has implemented various initiatives to stimulate exports, no formal inquiry has been made on factors that determine both the manufacturing firms' propensity and intensity to export in Zimbabwe. Besides being potentially a major solution to Zimbabwe's current liquidity crisis, an understanding of the determinants of export performance is particularly important in today's business environment given the steady rise in global business and the intensification of global competition, (Sousa, 2004). Exporting activities have become increasingly important for the survival, growth and longterm viability of firms (Dana \& Wright, 2005; Knight \& Kim, 2009; and Muzychenko, 2008). There is a need therefore to carefully examine the factors that that influence both the propensity and the volume of exports.

Objectives: The objectives of this study are to;

- What determines the propensity and intensity to export of Zimbabwean firms in the multicurrency system?

- To provide evidence based policy recommendations on ways to improving the export performance of Zimbabwean manufacturing firms.

\section{Literature Review}

Theoretical literature on international trade patterns can be traced back to the neoclassical models on comparative advantage. According to the Hecksher - Ohlin model, countries export goods whose production is intensive in factors with which they are abundantly endowed. Labor abundant countries are therefore expected to have a relative advantage in labor intensive commodities. Hence, capital abundant countries would, therefore, export capital intensive goods, while labor abundant countries would export labor intensive goods. Self-selection models posit that only the efficient firms will participate in export markets. The reason for this expectation is that there are additional sunk costs of selling goods in foreign countries (Haidar, 2012), which forms a barrier that only efficient firms may overcome. Empirical literature has also investigated the impact various firm specific and business environment factors on firm export performance. Firm specific or organizational characteristics play a significant role in determining the success or failure of a company's export efforts (Muranda, 2003). Empirical literature has extensively studied the impact of firm age on firm export performance. Age captures the extent of a firm's learning through experience but its impact on export propensity and intensity is unclear a priori. Majocchi, Bacchiocchi, \&Mayrhofer (2005) found that age had a positive association with export intensity, and likelihood to export in the Finnish Electronics Industry.

There are mixed results in literature on the effect of financial leverage on export performance. Bernini et al. (2013) found that the financially healthier firms export expensive varieties in export markets; Akarim (2013) found no significant relationship between leverage ratios and export decisions in Turkey. Studies have also focused on Research and Development (R\&D) as a driver of export performance. R\&D measures the firms' potential to innovate, introduce new products or improvements of a firms' product range, which are critical in determining competitiveness. Roper \& Love (2002) found that product innovation (measured by R\&D) had a positive effect on firm probability and intensity to export in the United Kingdom and in Germany. Harris \& Li (2008) found that R\&D increases firms' propensity to export but did not increase the intensity to export in the UK. Firm size has also been studied as a potential driver of exports in empirical literature. Large firms are likely to be competitive through the benefits of economies of scale, a fuller utilization of specialized executives, and the benefits from bulk purchasing (Wagner, 1995). However, beyond a certain optimal point, size can create dis-economies of scale. Serra, Pointon \& Abdou (2012) found that large firms had a higher propensity to export than smaller firms in the UK and Portuguese textile industry. Harris \& Li (2008) found that size had a positive impact on propensity to export and a negative effect on intensity to export in the UK.

Firm ownership has also been cited and studied a key export driver. Multinational firms are expected to have more information about foreign markets (Fakih \& Ghazalian, 2013) which enhances their export performance. Moreover, MNC tend to have strong business relationships with firms located in foreign countries, especially those belonging to the same multinational group. Okado (2013) found that firms with 
some measure of foreign ownership had a higher propensity to export in Kenya. Exchange rate levels and volatility have also been cited as drivers of export performance. The use of the strong US dollar has been alleged to make Zimbabwe's export products uncompetitive. A major concern has been the exchange rate volatility between the US dollar and the South African Rand in view of the fact that South Africa is a Zimbabwe's major trading partner. The rand has been unstable and this has had negative effect on pricing of goods and competitiveness of Zimbabwe's manufactured goods in regional markets.

\section{Methodology}

The study was based on secondary firm level data from published financial reports of manufacturing firms listed on the Zimbabwe Stock Exchange. The study was based on longitudinal data with a cross section of nineteen (19) manufacturing firms over the period 2009-2017. Financial statements were accessed from the INET BFA Expert data base and from the Zimbabwe Stock Exchange. Only listed manufacturing companies were selected because they produce financial reports annually. Export performance in this study is reflected by two decisions; the propensity or probability to export, and the intensity to export, which is the relative share of exports in the total sales of a firm. The likelihood or propensity to export is a binary variable taking a value of 1 - if the firm exports and zero if otherwise, while intensity to export is a fractional value between zero and one. Propensity to export is often estimated using the binary choice models like linear probability models, logit or probit models, while the intensity to export has been estimated by Tobit models and fractional regression models. The propensity to export was estimated using the logit and the Tobit model was used to estimate Zimbabwean firms' intensity to export, with the ratio of exports to total sales censored on the left.

The empirical model for propensity to export was; EXP $_{i t}=\alpha+\beta_{1}$ Size $_{i t}+\beta_{2}$ RD $_{i t}+\beta_{3}$ Age $_{i t}+\beta_{4}$ Leverage $_{i t}+\beta_{5}$ Exrate $_{i t}+\beta_{6}$ Ownership $_{i t}+\varepsilon_{i t}$

The empirical model for intensity to export was; $E_{i t}=\alpha+\beta_{1}$ Size $_{i t}+\beta_{2} R D_{i t}+\beta_{3}$ Leverage $_{i t}+\beta_{4}$ Ownership $_{i t}+\beta_{5}$ Exrate $_{i t}+\beta_{6}$ turnover $_{i t}+$ $\beta_{7}$ Labourintensity $_{i t}+\varepsilon_{i t}$

\section{Definition of variables used in the estimation}

\begin{tabular}{ll} 
EXP & Is firm propensity or likelihood to export, it takes a value of 1 if the firm exports \\
and zero otherwise \\
EP & Is the fraction of exports to total sales for firm $i$ at a given time. \\
Exrate & Is the South African Rand to USD exchange rate \\
RD & Is research and development, it assumes a value of 1 is a firm is conducting \\
& research and development and zero otherwise \\
Leverage & Is the ratio debt to total assets of a firm \\
Age & Is the number of years of operation. \\
Turnover & Is log of domestic sales \\
Labor intensity & Is the percentage of labor cost to book value of plant \& manufacturing equipment \\
Size & Is the logarithm of total assets including intangible assets \\
\hline
\end{tabular}

\section{Results and Discussion}

The study was based on ten variables with an average of 144 observations per variable save for firm ownership and labor intensity. The mean age of the sampled firms was 61 years; the minimum age was 9 years and the maximum age was119 years. 
Table 1: Summary statistics.

\begin{tabular}{llllll}
\hline Variable & Observations & Mean & Std. Dev. & Min & Max \\
\hline Exports propensity & 144 & 0.5578 & 0.4983 & 0 & 1 \\
Export intensity & 144 & 0.1726 & 0.2440 & 0 & .9213 \\
Size & 144 & 7.3864 & 0.9179 & 4.8121 & 8.8476 \\
R \& D & 144 & 0.0833 & 0.2774 & 0 & 1 \\
Age & 147 & 61.9116 & 27.9407 & 9 & 119 \\
Leverage & 144 & 0.5130 & 0.1983 & 0.1246 & 0.9603 \\
Ownership & 74 & 17.6688 & 23.1197 & 0.02 & 80.33 \\
Turnover & 148 & 7.6487 & 0.5796 & 6.3094 & 9.0047 \\
Labor Intensity & 139 & 1.1993 & 1.9203 & 0.0394 & 16.0976 \\
Exchange Rate & 146 & 9.7423 & 2.4314 & 7.292 & 14.6969 \\
\hline
\end{tabular}

Table 2: Multicollinearity Test: Variance Inflation Factor

\begin{tabular}{ll}
\hline Variable & VIF \\
\hline Size & 1.51 \\
R \& D & 1.61 \\
Age & 1.75 \\
Leverage & 144 \\
Ownership & 1.65 \\
Turnover & 1.67 \\
Labor Intensity & 1.16 \\
Exchange Rate & 1.05 \\
\hline Mean VIF & 1.49
\end{tabular}

Table 3: Logistic and Tobit estimation of export propensity and intensity

\begin{tabular}{lll}
\hline Predictor variable & Export propensity (logit) & Export intensity(Tobit) \\
\hline Size & $1.6964^{* *}$ & 0.0022 \\
& $(0.4467)$ & $(0.0351)$ \\
R \& D & $3.6530^{* *}$ & $0.4492^{* * *}$ \\
& $(2.3526)$ & $(0.0741)$ \\
& & \\
Exchange rate & $1.2858^{* *}$ & $0.0266^{* *}$ \\
& $(0.1363)$ & $(0.0171)$ \\
Age & 0.9902 & -0.0005 \\
& $(0.0103)$ & $(0.0012)$ \\
Leverage & 1.6371 & 0.1298 \\
& $(2.1323)$ & $0.1527)$ \\
Ownership & 1.0216 & $0.0027^{* *}$ \\
& $(0.0156)$ & $0.0013)$ \\
Labor Intensity & - & -0.0172 \\
& & $(0.0141)$ \\
Turnover & - & $-0.1399^{* *}$ \\
& & $0.0672)$ \\
Constant & - & -0.3138 \\
& & $(0.2802$ \\
Wald $\chi^{2}(6)$ & $0.0003^{* * *}$ & \\
LR $\chi^{2}(8)$ & & $0.0000^{* * *}$ \\
Observations & & 101 \\
Censored & & 37 \\
Uncensored & & 64 \\
\hline Robs standard & & \\
\hline
\end{tabular}

Robust standard errors in parentheses. Log odds ratios are presented for logit model.

Significant at $10 \%$ : $\quad *$, Significant at $5 \%: \quad * *$, Significant at $1 \%$ : *** 
The ZAR/USD exchange rate depreciated from 7.25 to 14.70 over the period under consideration. On average $17.26 \%$ of Zimbabwe's manufactured goods are exported while $82.74 \%$ are sold domestically. A test for multicollinearity was done using the Variance Inflation Factor (VIF), and results are presented in Table 2 above. The results show that there are no linear relationships among the independent variables of this study. A mean VIF of less than 10 indicates no multicollinearity; therefore, all explanatory variables of the model were maintained. A logit model for the propensity to export was estimated, the results are shown in column 2 of Table 3 above. The Wald Chi-square test shows that the populated model for propensity to export is statistically significant at $1 \%$. Firm size, research and development and exchange rate have a positive and significant impact on Zimbabwean manufacturing firms' likelihood to export. Age, leverage and foreign ownership are statistically insignificant, suggesting that they possibly dot not play an important role in manufacturing firms' decision to export.

The results indicate that firms with a large asset base (size) are more likely to export, possibly because they benefit from economies of scale and fuller utilization of specialized executive which makes their products more competitive on the international market. The results are in line with findings of Harris \& Li (2008) and Serra, Pointon \& Abdou (2012) found that large firms had a higher propensity to export than smaller firms in the UK and among UK and Portuguese textile industry respectively. Results also indicate that firms that engage in research and development are more likely to export than those that do not engage in research and development. Research and development enables firms to improve their product ranges which is critical in determining competitiveness. The results are consistent with that of Roper \& Love (2002) who found that R\&D had a positive effect on firm probability to export in the United Kingdom and in Germany. Haris \& Li (2008) also that R\&D increases firm propensity to export.

The results also indicate that appreciation of the USD tends to increase Zimbabwean firms' probability to export. The results indicate that that due to the high reliance on imported inputs /high import content (e.g. electricity, raw material, intermediate goods, spares and new machinery) in Zimbabwean manufacturing sector, exports are not adversely affected by currency appreciation. Lower import prices due to appreciation of the USD reduce the cost of export production, and thus increase the likelihood to export. The results are similar to that of Abeysinghe \& Lin Yeok, (1998) who found that the appreciation of the Singapore dollar improved Singapore's export performance in the high import content export sectors. Results of the Tobit model for the intensity to export are presented in column 3 of Table 3 above. The results show that research and development, firm ownership, exchange rate and turnover are significant in determining the volume of exports of Zimbabwean manufacturing firms, while labor intensity, firm age and size were insignificant. The results show that firms that engage in research and development tend to export 0.4492more than firms that do not do research and development. The findings are similar to those of Zhao \& Li (1997) who found that high level of investment in R\&D induced higher volumes of exports in Chinese manufacturing firms. Research and development also give firms a temporary monopoly on the new or differentiated product which enhances export volumes in the short to medium term period.

Although foreign ownership did not affect the propensity to export, a unit increase in foreign ownership of a firm increases the volume of exports by 0.0027 units. Firms with foreign ownership are expected to have more information about foreign markets and stronger business relationships with firms located in foreign countries which enable them to sell more volumes in international markets. The results are similar to those of Rankin, Soderbom \& Teal (2004) and Fakih \& Ghazalian (2013). The volume of domestic sales was found to have a negative and significant impact on the volume of exports, a unit increase in domestic sales resulted in 0.1399 units decrease in volume of exports. The results indicate that firms that have established themselves and can sell large volumes in the domestic market may opt to concentrate on the domestic market thus reducing their volume of exports. Moreover, considering the current pricing distortions and the rampant profiteering that characterize Zimbabwean markets, firms find it more attractive to sell domestically than to export. The results are similar to the findings of Fakih\& Ghazalian (2013). Finally, a unit increase in the appreciation of the USD against the South African Rand increases the volume of exports by 0.0266 units. This indicates that as the cost of imported inputs go down due the appreciation of the USD against the South African Rand, Zimbabwean manufactured products become more competitive and thus higher volumes can be sold in international markets. The results are similar to that of Abeysinghe\& Lin Yeok, (1998) who found 
that appreciation of the Singapore dollar improved Singapore's export performance in the high import content export sectors.

\section{Conclusion}

This study shows that investment in research and development increases both the firm likelihood to export and the volume of exports. Bigger firms are more likely to export than small firms, but firm size does not affect volume of exports. Firms with higher domestic turnover tend to export less as they can make more profit by exploiting the current pricing distortions in Zimbabwe, firms with higher foreign ownership tend to have better knowledge of international markets and export more goods. Moreover, contrary to widely held notions the appreciation of the USD actually increases the propensity and volume of exports for Zimbabwe by making imported inputs cheaper.

Policy recommendation: The findings of this study have important policy implications for both management practice and public policy. Managers of firms should prioritize allocation of resources for research and development as it improves both the likelihood and intensity to export. Public policy makers should design investment laws that attract foreign investors who bring valuable information about international markets and increase export volumes. Lastly we recommend firm managers to take advantage of episodes of USD appreciation to recapitalize (import new machinery and spare parts) at a cheaper cost and export more goods since the economy's manufacturing production is highly import dependent.

\section{References}

Abeysinghe, T. \& Yeok, T. L. (1998). Exchange rate appreciation and export competitiveness. The case of Singapore. Applied economics, 30(1), 51-55.

Akarım, Y. D. (2013). The impact of financial factors on export decisions: The evidence from Turkey. Economic Modelling, 35, 305-308.

Bernini, M., Guillou, S. \& Bellone, F. (2013). Firms leverage and export quality evidence from France.

Dana, L. P., Etemad, H. \& Wright, R. W. (2008). Toward a paradigm of symbiotic entrepreneurship. International Journal of Entrepreneurship and Small Business, 5(2), 109-126.

Fakih, A. \& Ghazalian, P. (2013). Why some firms export? An empirical analysis for manufacturing firms in the MENA region.

Haidar, J. I. (2012). Trade and productivity: self-selection or learning-by-exporting in India. Economic Modelling, 29(5), 1766-1773.

Harris, R. \& Li, Q. C. (2008). Exporting, R\&D, and absorptive capacity in UK establishments. Oxford economic papers, 61(1), 74-103.

Knight, G. A. \& Kim, D. (2009). International business competence and the contemporary firm. Journal of International Business Studies, 40(2), 255-273.

Majocchi, A., Bacchiocchi, E. \& Mayrhofer, U. (2005). Firm size, business experience and export intensity in SMEs: A longitudinal approach to complex relationships. International Business Review, 14(6), 719738.

Mugumisi, N. \& Ndhlovu, N. M. (2015). In search of remittance mobilization strategies through formal channels in Zimbabwe: A survey of Zimbabweans living in South Africa and Botswana.

Muranda, Z. (2003). Relationships between firm characteristics and export constraints in SME exporters.

Muzychenko, 0. (2008). Cross-cultural entrepreneurial competence in identifying international business opportunities. European Management Journal, 26(6), 366-377.

Okado, A. D. (2013). Export Propensity and Intensity of Kenyan Manufacturing Firms: An Empirical Analysis. Journal of Emerging Issues in Economics, Finance and Banking (JEIEFB), 2(2), 638-654.

Rankin, N., Söderbom, M. \& Teal, F. (2004). Exporting from manufacturing firms in Sub-Saharan Africa: Micro evidence for macro outcomes. In African Development and Poverty Reduction: The Macro-Micro Linkage Conference (pp. 13-15).

Reserve Bank of Zimbabwe. (2015). Monetary Policy Statement: January 2012, (Government of Zimbabwe, Harare)

Reserve Bank of Zimbabwe. (2015). Monetary Policy Statement: January 2015, (Government of Zimbabwe, Harare) 
Roper, S. \& Love, J. H. (2002). Innovation and export performance: evidence from the UK and German manufacturing plants. Research policy, 31(7), 1087-1102.

Serra, F., Pointon, J. \& Abdou, H. (2012). Factors influencing the propensity to export: A study of UK and Portuguese textile firms. International Business Review, 21(2), 210-224.

Sousa, C. M. (2004). Export performance measurement: an evaluation of the empirical research in the literature. Academy of marketing science review, 2(1).

Wagner, J. (1995). Exports, firm size, and firm dynamics. Small Business Economics, 7(1), 29-39.

www.zimtrade.co.zw, Analysis of the manufacturing sector export performance, March 2016.

Zhao, H. \& Li, H. (1997). R\&D and export: An empirical analysis of Chinese manufacturing firms. The Journal of High Technology Management Research, 8(1), 89-105. 